\title{
A field research for the determination the influence of physicians' professionalism understanding on medical errors attitude
}

\section{Hekimlerin profesyonalizm anlayışının tıbbi hata tutumu üzerine etkisinin belirlenmesine yönelik alan araştırması}

\author{
E.Nisa Yayla ${ }^{1}$, Naim Karagöz ${ }^{2}$
}

${ }^{1}$ Department of Management of Health Institutions, Social Sciences Vocational College, Kayseri University, Kayseri, Turkey

${ }^{2}$ Medical Education Department, Department of Basic Medical Sciences, Faculty of Medicine, Sivas Cumhuriyet University, Sivas, Turkey

Corresponding author: Elif Nisa Yayla, Department of Management of Health Institutions, Social Sciences Vocational College, Kayseri University

Kayseri, Turkey

E-mail: elifnisayayla@kayseri.edu.tr

Received/Accepted: July 11, 2019,/September 24, 2019

Conflict of interest: There is not a conflict of interes

\begin{abstract}
SUMMARY
Objective: To determine the influence of hospital-based physicians' attitudes toward medical errors on professionalism understanding

Method: The research was carried out in a descriptive, cross-sectional, and interrogative design. The study was carried out at the Cumhuriyet University Hospital with 182 physicians. A survey form was used to collect data. The Cronbach alpha coefficient was calculated to be .809 .

Results: It was found that physicians' attitudes toward professionalism $(\overline{\mathrm{x}}=3.72)$ and their attitudes towards medical errors $(\overline{\mathrm{x}}=3.46)$ were positive. A positive correlation of $20.8 \%$ was found between the Professional Process sub-dimension and the Medical Error Perception subdimension. In the sub-dimension of professionalism, the score of the group of 41-50 age group was 21.52, while the score of the age group of 60 years and over was $25,40(\mathrm{p}<0,05)$.

Conclusions: It has emerged that the physician's understanding of professionalism is not effective on attitudes in medical errors.

Keywords: Professionalism, malpractice, medical error
\end{abstract}

Amaç: Hastanede çalışan hekimlerin profesyonalizm anlayışlarının tıbbi hatalarda tutum üzerine etkisinin belirlemesidir. Materyal ve Metod: Tanımlayıcı, kesitsel ve ilişki arayıcı olarak tasarlanan bu araşıııma, 12-24 Şubat tarihleri arasında Cumhuriyet Üniversitesi Sağlık Hizmetleri Uygulama ve Araştırma Hastanesinde evrenin \%52.44'ünü oluşturan 182 hekimin örnekleme dahil edilmesi ile gerçekleştirilmiştir. Çalışmada ölçeğin Cronbach alpha katsayısı .809 olarak hesaplanmıştır.

Bulgular: Hekimlerin profesyonalizm anlayışlarının $(\bar{x}=3,72)$ ve tıbbi hatalarda tutumlarınının olumlu $(\bar{x}=3,46)$ olduğu ortaya çıkmıştır. Profesyonelleşme Süreci alt boyutu ile Tibbi Hata Algısı alt boyutu arasında pozitif yönlü korelasyon bulunmuştur. Profesyonalizm alt boyutunda 41-50 yaş grubundakilerin puan ortalaması 21,52 iken 60 yaş üstü yaş grubunun puan ortalaması 25,40 olarak saptanmıştır $(\mathrm{p}<0,05)$.

Sonuç: Hekimlerin profesyonalizm anlayışlarının tıbbi hatalarda tutum üzerinde etkili olmadığı ortaya çıkmıştır.

Anahtar sözcükler: Profesyonalizm, tıbbi hata, malpraktis 


\section{INTRODUCTION}

Ethical and inappropriate conduct of a healthcare professional. In case of insufficient and negligent behavior in professional practice, the patient's damage is called a medical error. In medical error, the patient is either impaired by incorrect application or by neglecting the side effect.

As a result of increase in the number of applications to health institutions with Increase in the world population, development of technology, globalization, to make many transactions in health care services together and to be closely connected with each other, interference by unethical market forces, bioterrorism problems, some problems created in patient safety. One in every 10 patients hospitalized in the world is damaged by medical errors while at least $50 \%$ of them are preventable. It is estimated that the cost of permanent disability, psychological depression, decrease in professional performance, drop out, additional hospitalization, costs of litigation, hospital-acquired infections and loss of income are estimated to reach one billion dollars per year. The loss of dignity and reliability of the system and health services is added to all this. ${ }^{1}$

Professionalism; is an ideology that has a standard of the method, attitude, responsibility, point of view, autonomy and ethics in professional occupations and committed to developing them. ${ }^{2,3,4}$ Medical Professionalism is umbrella that medical, educational and sociological aspects ethics, leader, educator, such as other competencies. ${ }^{5}$ It was determined that Students of medical faculty who tend to humanity was a deviation in these behaviors in the following years. ${ }^{6}$ Medical professionalism was not officially mentioned in Tomorrow's Doctors (1993) report, but content reflecting medical professionalism fall within in this report. Which is a guide to physician candidates, the behaviors that physicians should comply with and avoid is listed in the revised report (2002). Professionalism was directly mentioned in the report 2006. ${ }^{7}$ Metallization of health with globalization has lead physicians think that they are not different from other professions. This raises the question of whether the understanding of professionalism of physicians may affect their attitudes in medical errors.

\section{MATERIAL AND METHODS}

The population of this cross-sectional study consisted of 347 physicians ( $\mathrm{N}=347$ ) working actively in Cumhuriyet University Health Services Practice and Research Hospital, which is a tertiary health institution providing clinical and polyclinic services between February 12-24. Based on the Acceptable Minimum Sample Size Table for the Different Population by Gürbüz and Şahin, 182 people were collected from $52.44 \%$ of the population. $^{8}$

Data were collected by a data collection tool consisting of two parts. These are the "Professionalism Scale" and the "Attitude Scale for Medical Errors." "9,10 The information about the scales is given below. All of the scales are 5-point Likert type scales. Scoring is as follows: (1) Strongly agree (2) Agree (3) Undecided (4) Disagree (5) Strongly disagree. Before the data collection tools were applied, Ethics Committee Approval was obtained from the Ethics Committee of Cumhuriyet University.

\section{RESULTS}

Of the 317 employees participated in the study, 1t's detected that $51.64 \%$ of the physicians participating in the research was in the 24-30 age group, $61.53 \%$ was married, $60.98 \%$ was male, $53.84 \%$ had $1-5$ years of professional work, $81.86 \%$ had chosen the profession consciously. 
Table 1: Distribution of the mean scores obtained from the professionalism scale and the attitude scale for medical errors

\begin{tabular}{|c|c|c|c|c|c|c|c|c|c|c|c|c|}
\hline & & \multicolumn{8}{|c|}{ Professionalism } & \multicolumn{3}{|c|}{ Medical Error Attitude } \\
\hline & $\mathbf{n}$ & $\begin{array}{l}\text { Professional } \\
\text { Information }\end{array}$ & $\begin{array}{l}\text { Professional } \\
\text { Association }\end{array}$ & $\begin{array}{l}\text { Professional } \\
\text { Ethics }\end{array}$ & $\begin{array}{c}\text { Vocational } \\
\text { Socialization }\end{array}$ & $\begin{array}{l}\text { Professional } \\
\text { Domination }\end{array}$ & Professionalism & $\begin{array}{l}\text { Professional } \\
\text { Process }\end{array}$ & $\begin{array}{c}\text { Professional } \\
\text { Closure }\end{array}$ & $\begin{array}{l}\text { Medical } \\
\text { Error } \\
\text { Perception }\end{array}$ & $\begin{array}{l}\text { Approach to } \\
\text { Medical } \\
\text { Error }\end{array}$ & $\begin{array}{l}\text { Causes of } \\
\text { Medical } \\
\text { Error }\end{array}$ \\
\hline \multicolumn{13}{|l|}{$\begin{array}{c}\text { Age } \\
\text { groups }\end{array}$} \\
\hline $24-30$ & 94 & 49,19 & 9,79 & 18,26 & 10,00 & 72,98 & 22,71 & 14,59 & 6,33 & 5,85 & 23,78 & 25,24 \\
\hline $31-40$ & 41 & 49,33 & 10,89 & 18,05 & 9,67 & 74,05 & 23,72 & 13,43 & 6,54 & 5,89 & 24,91 & 26,21 \\
\hline $41-50$ & 28 & 49,72 & 10,00 & 17,36 & 10,32 & 71,6 & 21,52 & 14,33 & 6,16 & 5,88 & 23,96 & 26,52 \\
\hline $51-60$ & 8 & 51,14 & 11,42 & 18,57 & 10,85 & 77,42 & 24,14 & 14,14 & 6,85 & 4,85 & 24,85 & 26,85 \\
\hline $60+$ & 11 & 53,50 & 10,60 & 19,20 & 11,10 & 77,9 & 25,4 & 14,00 & 5,70 & 4,90 & 23,20 & 24,20 \\
\hline \multirow{2}{*}{ Result } & & $\begin{array}{c}p=0,049 \\
f=9,54\end{array}$ & $\mathrm{p}=0,109$ & $\mathrm{p}=0,280$ & $\mathrm{p}=0,249$ & $\mathrm{p}=0,307$ & $\begin{array}{l}p=0,034 \\
f=10,38\end{array}$ & $\mathrm{P}=0,457$ & $\mathrm{P}=0,558$ & $\mathrm{p}=0,373$ & $\mathrm{p}=0,256$ & $\mathrm{p}=0,083$ \\
\hline & & \multicolumn{8}{|c|}{$\begin{array}{l}\mathrm{p}=\mathbf{0 , 0 3 5} \\
\mathrm{f}=\mathbf{1 0 , 3 1}\end{array}$} & \multicolumn{3}{|c|}{$\mathrm{p}=0,111$} \\
\hline \multicolumn{13}{|l|}{ Gender } \\
\hline Female & 71 & 49,18 & 10,24 & 18,13 & 9,93 & 73,77 & 23,42 & 14,49 & 6,60 & 5,88 & 23,42 & 25,19 \\
\hline Male & 111 & 49,90 & 10,15 & 18,12 & 10,11 & 73,23 & 22,65 & 14,03 & 6,15 & 5,68 & 24,51 & 25,98 \\
\hline \multirow{2}{*}{ Result } & & $\mathrm{p}=0,446$ & $\mathrm{p}=0,653$ & $\mathrm{p}=0,840$ & $\mathrm{p}=0,463$ & $\mathrm{p}=0,851$ & $\mathrm{p}=0,237$ & $\mathrm{p}=0,292$ & $\mathrm{p}=0,072$ & $\mathrm{p}=0,747$ & $\mathrm{p}=0,072$ & $\mathrm{p}=0,114$ \\
\hline & & \multicolumn{8}{|c|}{$\mathrm{p}=0,889$} & \multicolumn{3}{|c|}{$\mathrm{p}=0,060$} \\
\hline \multicolumn{13}{|l|}{$\begin{array}{c}\text { Marital } \\
\text { status }\end{array}$} \\
\hline Married & 112 & 50,29 & 10,14 & 18,08 & 10,06 & 73,03 & 22,88 & 14,13 & 6,34 & 5,71 & 24,29 & 25,75 \\
\hline Single & 70 & 48,63 & 10,33 & 18,16 & 10,00 & 74,13 & 23,08 & 14,41 & 6,30 & 5,83 & 23,73 & 25,55 \\
\hline \multirow{2}{*}{ Result } & & $\mathrm{p}=0,144$ & $\mathrm{p}=0,639$ & $\mathrm{p}=0,966$ & $\mathrm{p}=0,698$ & $\mathrm{p}=0,568$ & $\mathrm{p}=0,964$ & $\mathrm{p}=0,624$ & $\mathrm{p}=0,783$ & $\mathrm{p}=0,833$ & $\mathrm{p}=0,399$ & $\mathrm{p}=0,830$ \\
\hline & & \multicolumn{8}{|c|}{$\mathrm{p}=0,923$} & \multicolumn{3}{|c|}{$\mathrm{p}=0,677$} \\
\hline \multicolumn{13}{|l|}{ Title } \\
\hline Prof. & 22 & 52,00 & 10,85 & 18,80 & 10,90 & 76,57 & 24,42 & 14,52 & 6,19 & 5,14 & 23,71 & 25,42 \\
\hline $\begin{array}{l}\text { Assoc. } \\
\text { Prof. }\end{array}$ & 17 & 49,58 & 9,33 & 17,16 & 10,25 & 71,08 & 21,91 & 13,90 & 5,45 & 6,16 & 23,33 & 27,58 \\
\hline Asts. Prof. & 20 & 50,18 & 11,00 & 17,81 & 10,06 & 74,37 & 22,06 & 14,31 & 6,81 & 5,56 & 25,06 & 26,00 \\
\hline Specialist & 3 & 50,00 & 11,80 & 18,80 & 10,60 & 80,20 & 25,60 & 14,80 & 6,80 & 6,60 & 22,80 & 26,40 \\
\hline R. A. Dr. & 120 & 49,12 & 9,97 & 18,14 & 9,87 & 72,75 & 22,84 & 14,16 & 6,37 & 5,83 & 24,14 & 25,41 \\
\hline \multirow[b]{2}{*}{ Result } & & $\mathrm{p}=0,190852$ & $\mathrm{p}=0,143194$ & $\mathrm{p}=0,336729$ & $\mathrm{p}=0,346365$ & $\mathrm{p}=0,12919$ & $\mathrm{p}=0,141231$ & $\mathrm{p}=0,956934$ & $\mathrm{p}=0,135894$ & $\mathrm{p}=0,350173$ & $\mathrm{p}=0,486048$ & $\mathrm{p}=0,172312$ \\
\hline & & \multicolumn{8}{|c|}{$\begin{array}{l}\mathbf{p}=\mathbf{0 , 0 0 8} \\
\mathbf{f}=\mathbf{1 3 , 9 0}\end{array}$} & \multicolumn{3}{|c|}{$\mathrm{p}=0,604$} \\
\hline
\end{tabular}


Table 2: Correlations between Professionalism Scale and the Attitude Scale for Medical Errors Variables

\begin{tabular}{|c|c|c|c|c|c|}
\hline & & $\begin{array}{l}\text { Medical Error } \\
\text { Perception }\end{array}$ & Approach to Medical Error & Causes of Medical Error & $\begin{array}{l}\text { TOTAL MEDICAL } \\
\text { ERROR }\end{array}$ \\
\hline \multirow[t]{3}{*}{ Professional Information } & Correlation Coefficient & $-0,094$ & 0,016 & 0,003 & 0,000 \\
\hline & Sig. (2-tailed) & 0,236 & 0,837 & 0,972 & 0,998 \\
\hline & $\mathrm{N}$ & 182 & 182 & 182 & 182 \\
\hline \multirow[t]{3}{*}{ Professional Association } & Correlation Coefficient & $-0,059$ & 0,026 & $-0,014$ & $-0,023$ \\
\hline & Sig. (2-tailed) & 0,458 & 0,747 & 0,859 & 0,768 \\
\hline & $\mathrm{N}$ & 182 & 182 & 182 & 182 \\
\hline \multirow[t]{3}{*}{ Professional Ethics } & Correlation Coefficient & $-0,001$ & 0,153 & 0,049 & 0,107 \\
\hline & Sig. (2-tailed) & 0,990 & 0,052 & 0,532 & 0,175 \\
\hline & $\mathrm{N}$ & 182 & 182 & 182 & 182 \\
\hline \multirow[t]{3}{*}{ Vocational Socialization } & Correlation Coefficient & $-0,042$ & $-0,094$ & 0,065 & $-0,018$ \\
\hline & Sig. (2-tailed) & 0,596 & 0,235 & 0,411 & 0,821 \\
\hline & $\mathrm{N}$ & 182 & 182 & 182 & 182 \\
\hline \multirow[t]{3}{*}{ Professional Domination } & Correlation Coefficient & $-0,099$ & 0,064 & 0,039 & 0,026 \\
\hline & Sig. (2-tailed) & 0,212 & 0,419 & 0,625 & 0,746 \\
\hline & $\mathrm{N}$ & 182 & 182 & 182 & 182 \\
\hline \multirow[t]{3}{*}{ Professionalism } & Correlation Coefficient & $-0,146$ & $-0,060$ & $-0,035$ & $-0,085$ \\
\hline & Sig. (2-tailed) & 0,063 & 0,447 & 0,655 & 0,283 \\
\hline & $\mathrm{N}$ & 182 & 182 & 182 & 182 \\
\hline \multirow[t]{3}{*}{ Professional Process } & Correlation Coefficient & ,208 ${ }^{* *}$ & $-0,123$ & $-0,027$ & $-0,059$ \\
\hline & Sig. (2-tailed) & 0,008 & 0,121 & 0,737 & 0,460 \\
\hline & $\mathrm{N}$ & 181 & 181 & 181 & 181 \\
\hline \multirow{3}{*}{ Professional Closure } & Correlation Coefficient & $-0,105$ & 0,018 & 0,056 & 0,016 \\
\hline & Sig. (2-tailed) & 0,185 & 0,823 & 0,483 & 0,841 \\
\hline & $\mathrm{N}$ & 181 & 181 & 181 & 181 \\
\hline \multirow[t]{3}{*}{ TOTAL PROFESSIOANALISM } & Correlation Coefficient & $-0,098$ & 0,046 & 0,042 & 0,012 \\
\hline & Sig. (2-tailed) & 0,221 & 0,565 & 0,600 & 0,882 \\
\hline & $\mathrm{N}$ & 179 & 179 & 179 & 179 \\
\hline
\end{tabular}


It was determined that physicians' attitudes toward professionalism $(\overline{\mathrm{x}}=3.72)$ and their attitudes towards medical errors $(\overline{\mathrm{x}}=3.46)$ were positive.

A positive correlation of $20.8 \%$ was found between the Professional Process sub-dimension and the Medical Error Perception sub-dimension.

According to the gender of the participants, there was no statistically significant difference according to marital status, titles, gender in terms of Professionalism and Attitude in Medical Errors ( $p>$ 0.05).

In the Professional Knowledge subscale, the sum of scores for the 24-30 age group was 49.19, while the score for the age group of 60 years and over was $53.50(\mathrm{p}<0.05)$. In the sub-dimension of professionalism, the score of the group of 41-50 age group was 21.52 , while the score of the age group of 60 years and over was 25,40 $(\mathrm{p}<0,05)$.

It has emerged that the physician's understanding of professionalism is not effective on attitudes in medical errors.

\section{CONCLUSION}

Professionalization consists of three main process periods as professionalization, proletarianization, and corporatization. If we consider the events like easy access to physicians, non-proficient demonstration of financial interests, and is represented with a bad image in the media and deprofessionalization process, which is considered a decline in the professionalization process, it was determined that $14.8 \%$ of the physicians said "I completely agree", $32.7 \%$ said "I agree", $28.4 \%$ said "I am indecisive" to the statement "My profession has lost its professional status". According to this finding, nearly $47 \%$ of physicians think that their professional status decreased. However, in this respect, it should not be ignored that all professions have faced loss of prestige and status.

In light of the findings, it is possible to argue that the attitudes of the physicians who participated in the study were positive in medical errors. When similar studies conducted on the same subject in the literature were evaluated, it was determined that although Madigosky (2006) reported parallel results, Güleç (2012) reported opposite results. In the study that was conducted by West et al. (2006), they detected a relation between medical error perception, burnout, empathy, anxiety, and stress; and Shanafelt (2010) reported that there was no relationship between gender and medical error perception..$^{10,11,12,13}$
To the statement "Medical errors are caused by system deficiencies," a total of $7.4 \%$ of the physicians said "I completely agree," $48.1 \%$ said "I agree," 34.0\% said "I am indecisive." As a matter of fact, Özata and Altunkan (2010), Adems and Garber (2007), Özdilek (2006), Yildırım et al. (2009) and Saygin (2014) reported results that support the findings of our study. ${ }^{14,15,16,17,18}$

A relation was found between the Professionalization Process and Medical Error Perception. In the deprofessionalization process, which is also defined as the decline period, loss of beliefs in expectations and authority on the services of the professionals, loss of expectations and authority, breakdown in the monopoly of knowledge, working under organizations as paid employees responding to an employer instead of individual work may have affected the medical error perception.

\section{REFERENCES}

1. WHO-Patient Safety Making Health Care Safer 2017, http: apps.who.int iris bitstream handle $10665255507 \quad$ WHO-HIS-SDS-2017.11 eng.pdf;jsessionid $=0 \mathrm{E} 19 \mathrm{~A} 08 \mathrm{~A} 640 \mathrm{FEC} 5273 \mathrm{~A} 8$ BA94C812DC36? sequence $=1,(12.02 .2018)$

2. Swick H. M. Toward a Normative Definition of Medical Professionalism. Academic Medicine : Journal of the Association of American Medical Colleges 2012; 75;612-6.

3. Kurutkan, M. Hekimlerin Profesyonelleşme Anlayışı. Sakarya Üniversitesi Sosyal Bilmler Enstitüsü. Doktora Tezi. 2010

4. Baltaş, Acar (2003). 'Başarı İçin Pasaport: Profesyonel Davranış’, Kaynak Dergisi, 14.

5. Midık, Ö, Özbenli T, Pekşen Y. Tıbbi Profesyonalizm Bağlamında Tasarlanan Hekim Rolleri Seçmeli Programının Müfredata Entegrasyonu. Tıp Eğitimi Dünyası 2015;43.

6. Özan, S. Tipta Profesyonalizm Eğitimi. Tıp Eğitimi Dünyası. Özel Sayı. Iv. Ulusal Tıp Eğitimi Kongresi 2-5 Mayıs, Adana

7. General Medical Council. (2006). Good Medical Practice (GMC Recommendations). GMC, London, 1-52, http: .gmc-uk.org static documents content GMP_0910.pdf , (14.02.2018)

8. Gürbüz S., Şahin F. Sosyal Bilimlerde Araştırma Yöntemleri. Seçkin Yayıncılık. Ankara 2015.

9. Güleç D; İntepeler Ş. Tıbbi Hatalarda Tutum Ölçeğinin Geliştirilmesi. Hemşirelikte Araştırma Geliştirme Dergisi 2013; 15(3): 2641

10. Madigosky W, Headrick L, Nelson K, Cox K, Anderson T. Changing and Sustaining Medical Students' Knowledge, Skills, and Attitudes 
about Patient Safety and Medical Fallibility. Academic Medicine 2006; 81 - 1 : p 94-101

11. West C, Tan A, Habermann T, Sloan, J, Shanafelt T. Association of Resident Fatigue and Distress With Perceived Medical Errors. JAMA 23 30, 2009-Vol 302, No. 12

12. West C, Huschka M, Novotny P; Sloan J, Kolars, Joseph C; Habermann T; Shanafelt T. Association of Perceived Medical Errors With Resident Distress and Empathy.JAMA 2006; 296, 9:1071

13. Shanafelt T, Balch C, Bechamps G, Russell T, Dyrbye, L, Satele D, Collicott P, Novotny P, Sloan J, Freischlag J. Burnout and Medical Errors Among American Surgeons. Annals of Surgery 2010; 251(6).

14. Yıldırım A, Aksu M, Çetin İ, Şahan A. Tokat İli Merkezinde Çalışan Hekimlerin Tıbbi Uygulama Hataları ile İlgili Bilgi, Tutum ve Davranışları. Cumhuriyet Tıp Dergisi 2009; 31: 356-366.
15. Saygın, T. Sağlık Hizmeti Kullanıcılarının Tıbbi Hatalar Hakkındaki Görüşlerinin Değerlendirilmesi. Yüksek Lisans Tezi. 2014

16. Özdilek, A. Tıpta Yanlış Uygulama (Malpraktis) Sebebiyle Hekim Sorumluluğu", http:/ / .hayad.org.tr/tipta-yanlis-uygulamamalpraktis-sebebiyle-hekimin-hukukisorumlulugu , (17.11.2017)

17. Özata M, Altunkan H. Hastanelerde T1bbi Hata Görülme Sıklıkları, Tıbbi Hata Türleri ve Tıbbi Hata Nedenlerinin Belirlenmesi: Konya Örneği.Tıp Araştırmaları Dergisi 2010; 8: 2: 100-111.

18. Adams J, Garber S. Reducing Medical Malpractice By Targeting Physicians Making Medical Malpractice Payments. Journal of Empirical Legal Studies 2007;4: 185-222. 